\title{
"I wanted to see how to make money there too": Mobility strategies of Romanian seasonal workers in the agricultural sector abroad
}

\author{
Alexandra Voivozeanu ${ }^{1 *}$ \\ ${ }^{1}$ University of Liège, Centre for Ethnic and Migration Studies (CEDEM), Bâtiment 31 - Boîte 45, Quartier Agora \\ 3, Place des Orateurs, 4000 Liège, Belgium.
}

\section{KEYWORDS}

Migrant agency

Seasonal workers

Romanian migrants

Migration in agriculture

Labour migration

\begin{abstract}
A BSTRACT
Drawing on interviews with key informants and seasonal workers in Germany, Spain, Italy, Austria and the UK, and on non-participant ethnographies, this paper demonstrates that, despite various limitations associated with work in the agriculture sector, migrants strategically choose the times and destinations of their trips abroad, taking into account a variety of factors, including family commitments, economic goals at the origin, wages and working conditions, health issues and welfare opportunities. The findings illustrate that, depending on their commitments and economic objectives, Romanians who work in agriculture develop different mobility practices. While some work abroad only occasionally, when they need to supplement their home-country income, others engage in circular migration or extend the periods of time they spend abroad. In host countries, most workers try out various jobs and typically get involved in repeated migration once they have found a suitable arrangement. Some workers combine seasonal work in one or more countries of destination, over the course of the same year, with the aim of securing income for longer periods of time, while others opt for long-term migration or move into sectors that offer better opportunities.
\end{abstract}

*Contact address: mavoivozeanu@uliege.be (A. Voivozeanu) 


\section{Introduction}

Recent research shows that part of the migration which occurs within Europe is short-term and fluid (Engbersen et al. 2010, Wagner and Hassel 2016). While a body of work explains the structural factors that lead to precarious employment for (short-term) migrants (Anderson 2010, Kalleberg 2009, Voivozeanu 2019), less attention has been paid to migrant agency and migrants' strategies for coping with low wages and poor working conditions (Alberti 2014, Berntsen 2016, Datta et al. 2007, Rogaly 2009).

Against this background, the present paper analyses the mobility strategies of Romanian seasonal agricultural workers from a home-country perspective. The analysis is based on interviews and non-participant ethnographies, carried out in an area that has a consistent history of migration, with both key informants and seasonal migrants who work in Germany, Spain, Italy, Austria, and the U.K. The main argument of the article is that, despite forming part of one of the most precarious economic sectors, seasonal workers make use of their mobility resources to choose the times and spaces of their migration strategically, thereby taking into account a variety of economic and non-economic rationales. The findings show that, depending on their commitments and economic objectives, Romanians who work in agriculture develop different mobility practices. While some work abroad only occasionally, when they need to earn more money than at the origin, others engage in circular migration or extend the periods of time they spend abroad. In host countries, most workers try out various jobs and typically get involved in repeated migration once they find a suitable arrangement. Some workers combine seasonal work in one or more countries of destination, throughout the same year, with the aim of securing income for longer periods of time, while others resort to long-term migration or move into sectors that offer better opportunities.

In Sava (fictional name), a village in the north-west of Romania, part of the first departures in the agriculture sector coincided with recruitment carried out via bilateral agreements signed between Romania and Germany (1999) and Romania and Spain (2002). The agreement with Germany allowed 
for an annual quota of 17,000 to 18,000 workers, employed in various economic sectors, who could undertake work for up to three months in their country of destination. In practice, however, this recruitment scheme focused on agricultural workers (Diminescu 2004). The number of workers sent to Spain - who could hold a job in the country of destination for up to nine months - varied depending on the availability of employment opportunities in the country of destination (Diminescu 2004, Şerban, Molinero-Gerbeau and Deliu, 2020). Even after Romania's accession to the E.U., recruitment continued to be carried out through bilateral agreements until transitional restrictions were lifted - in 2009 in Spain and 2014 in Germany. In the last few years, Romanians have remained important providers of seasonal agricultural work for high-income countries in the European Union (Wagner and Hassel 2016a).

In an attempt to shed light on how Romanian seasonal workers exercise agency, the following sections of this paper will consider the external conditions under which their employment abroad occurs, thereby analysing the limitations of seasonal work in agriculture, as well as the opportunities migrants take in order to overcome them. At the same time, for the purpose of comparing their status abroad and articulations of agency with those of Romanians, the article will briefly discuss the limitations and opportunities of other migrant groups relevant to agricultural work in host countries. The factors that informants take into account when choosing their jobs, which are also examined, point to the fact that most of them are home-country oriented. Therefore, instead of working for longer periods of time abroad, migrants often decide to remain in such precarious, short-term employment, as it allows them to make ends meet while they prioritise their lives at home.

\section{Agency in migration studies}

In migration studies, agency is often conceptualised based on the theory of structuration (Giddens 1984), according to which agency and structure can only occur interdependently: "structure exists, as time-space presence, only 
in its instantiations in such practice and as memory traces orienting the conflict of knowledgeable human agents" (Giddens 1984: 17). However, recent work argues that a more refined view of the agency-structure duality would be more useful when theorising mobilities (Blackwell 2010). In this regard, Blackwell shares the view of critical structuralists for whom social structures are "outcomes of agency which 'emerge' or pass a developmental threshold beyond which they exercise their own causal power independently from the agency that produced them" (Parker 2000: 73 in Bakewell 2010). Therefore, they argue, an appropriate analytical framework should take into account the fact that the activities undertaken by a social actor in the present will have an influence over social structures in the future.

Another body of work discusses the self-determination of agency in migration (Mezzadra 2004, Nyers 2015, Papadopoulos and Tsianos 2013). The authors theorise "autonomous migration", a perspective which regards migration "not simply as a response to political and economic necessities but as a constituent force in the formation of polity and social life" (Papadopoulos and Tsianos 2013: 184) and "as a capacity to develop its own logics, its own motivations, its own trajectories that control comes later to respond, not the other way round" (Transit Migration Forschungsgruppe 2006 in Papadopoulos and Tsianos 2013: 184). While this is the case for various types of migration, in the present case, seasonal work in agriculture seems to be prompted largely by economic reasons rather than by any urge to relocate. Even in this context, however, workers develop strategies beyond state control.

Research into the agency of migrants mainly addresses their capacity to exercise collective power within unions (Fitzgerald and Hardy 2000, Juravich 2001, Milkman 2000, Berntsen 2015). Only a few studies focus on workers in short-term employment in Europe. Brentsen (2016) explains that, instead of challenging the present employment relationship framework, mobile construction workers use different individual strategies to improve their working conditions. However, she argues, this has no impact on the overall employment context. Alberti (2014: 877) shows that migrants use their 
mobility resources to find jobs that better suit their interests, "including, family, friendships, local and transnational communities." The author revises the concept of "mobility power" (Smith 2006), which was originally used to explain how favourable working conditions can be obtained by means of the individual or collective threat of employees to quit, since this might determine employers to improve the workers' conditions in order to avoid possible turnover costs. Alberti (2014: 877) goes beyond this initial framework and argues that "migrants use their quitting potential for reasons that often exceed a mere economic rationale and are independent from their identity as workers".

\section{Precarity in temporary jobs in agriculture}

Several studies show that migrant labour was among the factors that fostered growth in agriculture in the Mediterranean area (Gertel and Sippel 2014, Cole and Booth 2007, Lawrence 2007, Corrado, de Castro, Perrota 2016). Lawrence (2007) explains that the social and political exclusion of migrants assisted the expansion of a neoliberal market in the sector and that it was a key factor for the successful integration of Greek agriculture into the agri-food regime proposed by the European Union. In their analysis of three precarious economic sectors in Sicily, Cole and Booth (2007:6) explain that "the salience of networks and ethnic and racial stereotypes makes plain the nature of interactions between immigrants and employers". Within this process, the authors argue, families of migrants bear the brunt of high personal costs for the sake of enormous consumption in Europe. Gertel and Sippel (2014) introduce the concepts of "flexicurity" and "flexiprofity" in order to describe the new combinations of flexibility, insecurity and profitability which occur as a result of the new organisational process within the agricultural sector.

A different body of research links temporary work programmes, which encompass part of the temporary migrants in the European agricultural sector, with precarious employment conditions. The emergence of such programmes has been determined by employers, whose interests have been 
prioritised, as Molinero and Avallone (2018) argue, after comparing three areas with extensive agriculture in Spain and Italy. Simultaneously, the contracts were issued for limited periods of time and entailed return to the workers' country of origin, so that circularity was encouraged and migrants were prevented from acquiring permanent resident status in Spain (LopezSala 2016). The same goes for Germany, where seasonal employment (present both before and during the transitional restrictions imposed after the accession of the EU2 and EU8 countries) has become a permanent feature of the labour market (Wagner and Hassel 2016b). Obviously, the temporality of migrants in agriculture has consequences on employment relationships. Polish workers recruited through temporary work programmes are not familiar with their labour rights and are rather reluctant when it comes to standing up to employers (Fialkowska and Piechowska 2016). Similarly, short-term migrants are less motivated to inform themselves about the welfare system in Finland (Helander, Holley and Uuttana 2016).

\section{Description of the village}

In 2011, at the last Romanian census, Sava, a village situated in Romania's north-west, had about 6,000 inhabitants. The residents engage in small-scale animal husbandry and agricultural work or are employed in the logging industry and the village's few businesses. Only a small number commute to nearby towns to pursue employment in the industrial and textile sectors. The occupational range was similar during the communist regime, when employment was limited to the logging industry, large-scale animal husbandry, and a textile factory. A key element to explain the community's rich culture of migration is linked with the significant number of locals involved in internal migration, even before 1989. They used to work in the logging industry in Sibiu and Caraş-Severin counties or in agriculture, in Maramureș County.

Interviews with key informants reveal the chronology of labour migration abroad. The pioneers, who explored Spain and Italy, worked 
mainly in the construction and cleaning sectors. Others were recruited by companies from the logging industry in Germany (after initially working in Sibiu county - an area known for its German heritage). As regards work in agriculture, in the initial stages many of the inhabitants were recruited via bilateral agreements signed with Germany and Spain. In time, the migrants involved in these programmes stimulated departures of their families and neighbours. After 2007, when Romania became part of the European Union, several foreign employers, from Germany and Spain, visited the village in order to recruit additional workers (interviews with workers). On the other hand, prospective migrants who were not referred by families or acquaintances resorted to brokers or recruitment companies. In contrast to Germany and Spain, recruitment to Italy is more likely to be carried out with help of informal brokers.

The village council estimates that one third of the village's inhabitants are involved in labour migration: 900 employed in the logging industry, mostly in Austria (agreements with their companies allow them to return to the village, for one week, every one and a half months), 600 long-term migrants employed in the construction and cleaning sectors in Spain, Italy and Germany, and 300 seasonal agricultural migrants in Germany, Spain and Italy, Austria and the United Kingdom. Migrants are also currently employed in small numbers in Belgium, Sweden and Norway, while Switzerland and Israel were indicated as past destinations. The high number of inhabitants involved in permanent or temporary migration and their wide range of destinations point to the presence of a "migration culture" and rich mobility resources available at a community level. This is not necessarily common for other locations: other studies do not point to Romanian villages as departure sites for various destinations (Şerban, Molinero-Gerbeau and Deliu 2020). Similarly, more than 1,800 people and their families are impacted by migration, with visible effects on the local community. While only few businesses started up using money earned abroad, local firms have begun to hire Asian workers (interview with key informant), who as a result of their employer-arranged migration are more dependent and easier to control. At 
the same time, the price of land has risen in the area, as many of those who work abroad invest in (new) houses. Large houses, very probably built with remittances, are highly visible in the village.

\section{Methods and data}

The article is based on sixteen interviews with migrants who are or have been involved in seasonal migration in agriculture and with three key informants originating from the same village in Romania, as well as on non-participant ethnographies. The fieldwork stems from a larger project on recruitment channels in agriculture and it was carried out between January and March 2020. I approached the migrants via personal contacts, with help of local authorities and key informants - a priest, a family doctor and a local councillor-, as well as one high-school teacher, who agreed to connect me with both students and parents involved in seasonal migration in agriculture. In order to select key informants in Sava, I asked personal contacts to refer me to inhabitants of the village who are familiar with its history of migration. Through their positions, the three key informants have, for the last twenty years, been in contact with a large number of migrants. The priest officiates part of the public events in the village, visits most houses a few times a year, in line with religious practices, and holds confessions for some seasonal workers, primarily women, before each departure. The physician is often paid a visit before departures, too, as migrants want to make sure that they perform optimally abroad. At the same time, for tax purposes, at least those who work in Germany, need a document from the village hall stating that they are not employed in Romania. Similarly, when both parents are abroad a child's guardian is registered with local authorities.

I used the snowballing method-requesting recommendations for future respondents from the ones I had already interviewed. The interviewees form a heterogeneous group including five men and twelve women, aged eighteen to sixty-five. Twelve migrants are married, two are divorced and fourteen have children. Five entered seasonal agricultural migration via the 
bilateral agreements with Germany and Spain, in the early 2000s. One man moved to Spain in 2006 with his brother and found employment thanks to his social network. The rest were recruited, after 2007, via strong or weak ties, or resorted to informal brokers (whom they paid a recruitment fee). Only one has a permanent job at the origin. Most migrants work or have worked in the agricultural sector in Germany (13), Italy (7) and Spain (6), while Austria and the U.K. attracted a smaller number of respondents (two and one respectively). In Germany and Spain, migrants are typically employed on large scale/industrial farms, in Italy work is mostly carried out on familyowned farms. Eleven informants have worked in more than one country of destination: nine of them had jobs in agriculture, while two worked in a different sector. Twelve worked with the same employer for more than one season. The interviews covered the informants' entire migration trajectory. Among other topics, I was interested in how respondents made use of migration-related information available at a community level (and beyond), as well as in the factors that influence their decision to take one particular job over another. In order to protect the migrants' identities, pseudonyms are used throughout the article, both for their names and for that of their place of origin and, in one case, occupational details are omitted.

\section{Limitations of seasonal work abroad in the agriculture sector}

For some workers, one limitation of migration in agriculture is related to the short-term jobs on offer. While most respondents are unwilling or unable to spend longer periods of time abroad, due to commitments in their country of origin, others assemble seasonal jobs in different E.U. countries in order to secure employment for extended periods of time. Moreover, temporary work abroad, combined with periods of inactivity at the origin have a serious impact on the welfare and life opportunities of migrants: most interviewees are excluded from unemployment and pension benefits.

Simultaneously, other constraints are determined by the power dynamics between employers, who are interested in increasing levels of 
productivity, and seasonal workers. Jobs are often low paid, involve substandard working conditions, as well as high fees for food and accommodation, surveillance, and control mechanisms imposed by farm owners. Maria, for instance, likens her first seasons in Germany, in the early 2000s, to being in "the army". Every morning, at 4.30 a.m., workers assembled in teams in front of their sleep containers (shared with up to fourteen colleagues) in order to wait for their employer, who could be up to one hour late: "You had to be there at the set time and you were not allowed to leave until he [the employer] arrived. When he was speaking, you weren't allowed to breathe a word, unless you wanted to be sent home." After being instructed on their tasks for the day, the migrants went to work and were not allowed to stop, even if was raining "hailstones and lightning" or if one of their colleagues fainted because of the heat: "The colleague would lie on the ground. She [the field supervisor] would come, they would revive her and take her away [...] you were not allowed to get close, you had to keep working. How hard that was." At noon, when it was too hot, migrants rested for three hours and returned to work until it was too dark to see the strawberries. Visits were forbidden and workers were not allowed to leave the farm without permission either. According to Maria, conditions improved once Romania entered the European Union: "we worked less and we returned with more money". They worked for eight hours a day; their employer was less "harsh" and "only" four or five workers shared a room.

In time, advances in technology have helped employers improve the surveillance and control mechanisms used for tracking migrants' pace of work. Ana and her partner Mihai explain, for example, that the machines used at their asparagus farm are equipped with both a GPS device and a mobile phone with a camera attached (the latter allows managers to see each worker on the field). If the machine stops moving for more than "one or two minutes", even if employees are paid by kilo of asparagus harvested, the field supervisor will be informed by managers and will have to ask the migrant to get back to work. On a similar note, employers prefer to exclude workers who are not able to reach their desired level of productivity and who are unable to comply with their instructions (such as that of harvesting 25-cm-long pieces of 
asparagus). By setting a piecework rate payment, employers exploit migrants' goal to maximize gains abroad and stimulate competition between workers. Piro and Sanò (2017) show that nationality, types of contracts, and religion are apparent reasons for conflicts that are, in fact, stimulated by the workers' fragile position within the production system of the Italian agriculture sector. In the case of Ana and Mihai, since every day each team has only one plot allocated, migrants need to work very fast in order to be the ones that start harvesting the last asparagus rows: "you have to work hard, to get as many rows as possible [...] if one has four rows more, of course, there are more kilos, and they can earn 100 euro and you can earn 20 [...] [you keep working] and just ignore the fact that you are not able to keep up the pace."

Even if low wages and similar circumstances to those described in this section are common in the agriculture sector, because of their vulnerable positions, Romanians do not typically challenge their employment conditions. Instead, however, many of the workers seek jobs that offer better conditions.

\section{Opportunities for seasonal work abroad in the agriculture sector}

One opportunity Romanian seasonal workers take advantage of in their search for better positions is their ability to move freely within the European Union. In 2014, after the transitional restrictions had been lifted and Romanians were granted free access on the labour markets of Member States, the cost of migration decreased significantly for them. In contrast with temporary migration programmes, which led to employer dependency, seasonal migrants are currently able to quit unsatisfying jobs and either return to Romania or sign another contract abroad. At the same time, Sava has a substantial history of labour migration to several countries of destination and a high number of inhabitants working abroad. In the words of one key informant: "there is almost no household without one or two people who have gone abroad". In this context, a complex migration infrastructure (Xiang and Lindquist 2014), involving social networks, brokers and recruitment 
companies, has developed.

In order to find suitable jobs, some interviewees fall back on their social networks (which may expand beyond the village). For many prospective migrants, opportunities are available as soon as they enter migration, as in the case of Elena, an eighteen-year-old high-school student. For both economic reasons and the sake of a new experience, she decided to engage in seasonal agricultural migration and, thanks to an acquaintance, started working at a strawberry farm in Germany. There, a co-worker from the same village asked Elena to replace her at an Italian cherry orchard, a few weeks later. She accepted and after comparing the experiences, returned only to Italy the following year because the job in Germany involved "too much physical effort." Similarly, many of the young people in the village are encouraged to enter migration as soon as they are able. At eighteen, Andrei has already worked abroad for two seasons in privately owned orchards in Italy. He and his two brothers (one of them below the working age) joined their parents in Italy, even if school-time slightly overlapped with work abroad.

For prospective migrants, jobs recommended by trusted contacts reduce the risk of labour abuses. In the following quotation, Irina explains that she decided over a job in Germany when a friend, a migrant who worked with the same company for several years, informed her on the wage and working conditions:

R: I trusted her because I knew her as a friend... I found out that she [Irina's friend] was recruiting. I said, ok . . I will sign up for it and if I like it, I'll stay. If not, I'll stop going . . . She told me: Irina, don't you want to come to [harvest] strawberries? It's a serious firm, not a scam ...

I: Did you have other offers to go abroad?

$R$ : Yes, I heard of [other jobs] . . but you need to trust people if you're going to go abroad.

In 2020, Irina, who had in the meantime tried out working on an asparagus farm for one season, is still under contract with her first German employer. She missed two seasons after giving birth but now that her second child is old enough to stay at home with his grandmother for longer periods of time, Irina would like to continue working on the strawberry farm and is 
thinking about joining her colleagues who, after the season in Germany, harvest grapes in Italy.

Other migrants resort to brokers and recruitment companies, whom they contact either when they first go abroad, before developing an employment relationship that involves circularity, or simply when they become interested in exploring a new destination or a new job. The brokers who arrange jobs for respondents are typically, but not exclusively, based in Romania, very often in nearby areas and, in some cases, carry out agricultural work for the same employers. They fulfil different roles and responsibilities throughout the migration process: while some merely collect and organise documents, others offer extensive support, such as mediating in case of conflicts between migrants and employers and providing alternative work opportunities for those who have lost their jobs abroad. In most cases, in time, migrants form stronger relationships with employers and the services of brokers are rendered redundant. However, some brokers try to keep migrants dependent on their services, at least for a while, as happened in one of the following examples.

After reading the following announcement at the local mayor's office, I got in touch with Lina, a broker with a stable job in Sava who, for the last few years, has worked every summer with the same employer in Germany: "Registration - blueberry - for the year 2020. Eight or nine hours work a day. No work in the rain. Piecework rates payment - by the kilo, which means that you earn as much as you harvest."

In 2020, apparently without any selection criteria, Lina collected the personal data of twenty new workers interested in the positions she was advertising. In 2019, her employer mailed contracts for 168 Romanians, from Sava and other villages in the county, while the following year he aimed for 200. He signed a contract with a transport firm in a nearby town and deducts the cost of trip from the workers' wages at the end of their stay abroad. While the fee for seasonal job intermediation in agriculture ranges from 50 to 100 euros, Lina insists that she makes no profit out of the activity, either from the employer or from the migrants. However, she refuses to put me in touch with 
any of the new recruits.

Mihai and his partner, too, found a job through a broker - a Romanian woman who has lived in Italy for the last twenty-five years. She has a factory job and visits Sava regularly in search of prospective agricultural workers. The couple agreed to pay her fee of 100 euro only at the end of their stay abroad, which probably served as an incentive for the broker to provide additional support: "For example, if the Italian doesn't like you and after two days they throw you out in the street [...] she will do everything to find other work for you, so that you won't return without any money," Mihai explains. When he and his partner lost their jobs in Italy after just two days' work, the woman drove them $450 \mathrm{~km}$ to another farm, on the same day. Thanks to her services, the two migrants were certain that they would remain in seasonal employment in Italy. However, she referred them to a new employer every season, so that they would have to rely on her services the following year too. Mihai and Ana who, due to language barriers, were not able to communicate with their employers, had to pay the broker for several seasons, until, thanks to their son-in-law, they managed to find a longer-term arrangement on a farm.

Migrants make strategic use of the departure channels available at a community level. Mihai, for example, gained employment in Italy with help of a broker, was referred for a job in Germany by a neighbour, and even if he was involved in repeated migration to both destinations, resorted to the services of a company to find standard employment in the U.K. (a destination he had not thitherto pursued).

This section illustrated the ways in which seasonal workers use their available resources in order to find suitable jobs across borders. Their power of mobility (Smith 2006, Alberti 2014) relies on their free access to the labour markets of the E.U. states, the community's consistent history of migration, as well as its complex migration infrastructure (Xiang and Lindquist 2014). By means of the last two aspects, migrants gain information on wages and working conditions in various location and manage to move with ease despite often having limited resources in terms of organising trips abroad independently. 


\section{Seasonal workers abroad: articulations of agency}

A first articulation of agency on the part of migrants from Sava is the decision to go abroad in order to improve their economic circumstances, which are affected by a lack of jobs and the low salaries on offer in their local area. In their countries of destination migrants reported earning from 1.50 to 3.00 euros per kilo of blueberries harvested in Germany (the fee varies depending on the production), from 70 to 100 euros a day for harvesting strawberries in Germany, 6 euros an hour for apple picking in Italy.

What is more, seasonal workers choose the time and place of their migration taking into account various elements. For most respondents, seasonal work in agriculture is their only source of income throughout the year: only one of them is involved in long-term employment in the home country and very few do occasional/informal construction or manufacturing work. Even if some have worked abroad for periods of time longer than a few months, most interviewees are home-country oriented and are not willing to get involved in long-term migration. Therefore, they often plan migration in ways that allow them to prioritise (family) commitments in their home country.

For example, the migration trajectories of women often overlap with their roles as mothers, wives and daughters. Their migration projects are therefore planned taking into account their duty to provide care for their children, relatives with health issues, or elderly parents. Mihaela, a single mother of two, who has worked seasonally in Germany since 2012, explains that she prefers to go abroad during school holidays, when her children do not need such close supervision. In her first year abroad, even if she was satisfied with her initial job, at a mushroom farm, during winter, she tried out a second one in order to learn "how to make money there too". She decided on strawberry-picking, in which she still works, both because it pays better and because she can be with her children during school term time. Initially, Mihaela was not interested in working two jobs, because "there was school, there were the children", but she is considering spending longer periods of time abroad once her sons have finished secondary school. 
Another example of how women's migration trajectories are influenced by patriarchal family structures (Vlase 2013) is that of Diana, who explains that, after only one season abroad, her return to Spain was hindered by her husband, even if she could have worked at the same farm the following summer:

After that, I didn't go because ... I couldn't, he didn't allow me to go. I worked in the fields, we had animals ... I told him: "I went abroad and came back with a lot of money. You don't make that much money here". He said: "Forget about the money".

Over the following years, she left only with her husband's permission. After Spain, she harvested asparagus in Germany but decided not to return the next season, as the work was particularly gruelling. A few years later, she got a job on a salad farm and, again, even if she enjoyed the work, she had to stop after the first season, as her husband did not agree with her working abroad.

However, it is not only the paths of women that are influenced by familial commitments. For the past seven years, in order to secure an income for a longer period of time, Mihai and his partner, Ana, combined harvesting asparagus in Germany with working on an apple farm in Italy. As they wanted to overcome the insecurity of temporary work, the couple looked for stable employment. When Mihai finally obtained a full-time job in England, even though he was happy with it and the social security benefits that came with it, he quit after seven months because his wife was unable to get a job with the same company: "She cannot stay at home by herself, we are the type who stay together .. . otherwise the family will fall apart." Other migrants, too, mention that they prioritised jobs which allowed them to work together with family members or friends.

At the same time, obviously, economic rationales are also important for workers. While many complete seasonal works every year, others engage in migration only occasionally, when they would like to earn more than they do in Romania. Often, depending on plans and goals in their home country, migrants increase the length of time they spend abroad, as was the case with 
Lina. In 2012, when she quit her permanent position in Sava for a job at a vegetable warehouse in Austria, she was divorced, had two dependent children and a house under construction. Her new employment was stable and secured a higher income than in Romania: "I decided that I would keep going [abroad] because my house was under construction and I wanted to finish it." However, she put her contract at the warehouse on hold twice, when better paid opportunities arose. Once the construction was finished, she returned to working full-time in Romania and currently takes holidays from July to September to pick raspberries in Germany. Often, migrants strategically choose their job taking into account both the effort and the earnings involved. Even if the job is well paid, Mihai and Ana, for example, plan to stop harvesting asparagus because the pace of the work is too gruelling. Now that their children are financially independent and the couple has [modestly] invested in their house, they prefer to work only in Italy: "I can harvest apples in Italy for twenty years from now but with asparagus [...] you ruin your health." On a similar note, welfare opportunities also influence migrant trajectories: after working for the period of time necessary to receive unemployment benefits, with support of her employers, one woman stopped working in Spain and returned to work for them right after this.

Another example that describes the dynamic relationship between migrant agency, recruitment opportunities, and the factors determining seasonal workers to choose a particular job or country of destination is that of Iulia. She initially worked for five years as a strawberry-picker, as part of a bilateral agreement with Germany, but after experiencing acute back-pain, decided to try out a job at an asparagus farm in Germany. However, this work also injured her back, so she quit after the first season. The next year, Iulia started working as a fruit picker in Spain: "I thought it would be easier, you were paid hourly ... and it mattered that you didn't have to bend down while you worked ... It mattered that we were standing . . but there was the distance. You couldn't just go and come back every two months". Even though she was uncertain whether the new job would suit her expectations, she decided to try it: "I didn't know exactly if it would be better or worse, I decided to give it a try". She worked in 
the orchard for several years in order to support her daughter, who was employed at the same company. When her daughter found permanent employment in the cleaning sector in Spain, in order to avoid repetitive work, Iulia followed her sister into home care in Austria. Currently under a contract with a recruitment company, she works for one month in Austria and returns for one month to Romania - as a grandmother, she is not willing to spend longer periods of time abroad. Like other migrants, Iulia based her decisions on economic reasons, health issues and family commitments, and strategically chose between several destinations (Germany, Spain, and Austria), as well as short- versus long-term migration, in different economic sectors.

On a different note, in a few cases, the narratives of migrants regarding their work experiences abroad go beyond economic reasoning. Especially for women who are not employed in their home country, this is one of the few opportunities to engage in a non-private sphere, in Irina's words: "I used to go [abroad] just to leave home, to get away, because there are many months a year when . . . because I'm a housewife, I'm at home all the time".

The examples in this section show that migrants harmonise their job choice and the length of time spent abroad with their arrangements and plans in their home country, thereby taking into account a variety of factors, including family commitments, economic goals at the origin, wages and working conditions, health issues and welfare opportunities. At the same time, some describe migration not only as an opportunity to earn money, but also an enriching experience. This is consistent with Alberti's findings (2014), who argues that migrants select jobs based on reasons that go beyond their "identity as workers."

\section{Comparing Romanians with other migrant groups involved in agriculture}

In examining Romanians' articulations of agency, it is useful to compare their positions abroad, as well as their limitations and opportunities, to those of other relevant migrant groups involved in agricultural migration to the same countries of destination. As the informants' narratives confirm, in the recent 
years, Poles who worked in the agricultural sector have been replaced by Romanians who, in 2011, accounted for $93 \%$ of all registered seasonal workers (Wagner and Hassel 2016). Their status is considerably better than that of workers from Romania and includes access to stable employment and supervisory positions, in Lina's words:

They have Poles [who have worked with the company for 20 years], who are our bosses in the fields, they supervise us in the fields. They also work there over the winter, the plantation has to be cleaned and maintained [...] of course, they [the employers] started to give up on the Poles, because Romanians work harder. And I suppose that this year there will be even fewer Poles, because you know, the Romanians work hard, they want to make money ... [unlike] the Poles and the Germans.

While the migrant claims that employers prefer Romanians for their industriousness, what we are able to read between the lines is that their docility and willingness to accept lower wages than the Poles and native workers also play an important role. A study of Wagner et al. (2013) shows that migrants from Poland who work in the sector are paid considerably better than Romanians. This is probably the result of different opportunities for the two groups: Poles started working in the German agricultural sector and gained free access to the labour markets of Member States before Romanians, which strengthened their negotiating position and, at the same time, provided access to destinations and economic sectors that paid higher wages. At the same time, the higher wages in their home country possibly make temporary work in the German agricultural sector less attractive (Stark and Fan, 2007 in Wagner and Hassel, 2016). In Italy and Spain, on the other hand, Romanians have a better status than that of African migrants (Hellio 2008, Perrota 2013, Potot 2003). As regards the Italian agricultural sector, Perrota (2013) shows that, while migrants from Burkina Faso are mostly involved in seasonal migration and manual labour, Romanians often also perform mechanised labour and have stable jobs in agriculture or are also employed in other sectors too. This is mainly linked to the legal of status of the two migrant groups: hiring E.U. citizens informally involve less risk for Italian employers and might be more profitable since, due to their low migration costs, they often 
accept lower wages and, at the same time, irregular migrants from Burkina Faso are more vulnerable and easier to control due to their deportability (Perrota 2013).

\section{Mobility strategies of Romanian workers involved in the agriculture sector}

Informants have different approaches to seasonal migration depending on their plans and commitments in their home country. While some work abroad only occasionally, when they need to supplement their home-country income, others engage in circular migration or extend the periods of time they spend abroad. In host countries, only few remain under contact with the same employer for the entire period in which they are involved in transnational labour migration. This was the case for Maria who, initially, with a contract signed within the bilateral agreement between Germany and Romania, worked for a fruit and vegetable producer. However, even if she remained at the same farm, she sought to improve her position. For fourteen years, together with members of her family, she performed different types of seasonal work at the farm and gradually moved up to the highest-paid activities. Favourite workers have higher negotiating capital and better chances of obtaining their preferred roles.

We worked as strawberry pickers for five years. Then, we went back for two years in the autumn. In the second year, we didn't earn well in the autumn, so we went again in the spring . . a after that, we tried asparagus-picking, and we dragged each other along [...] we went there separately, because it was better, you were paid hourly.

Other migrants move between seasonal jobs until they find suitable arrangements. If invited to return to a satisfying position, they will usually get involved in repeated migration, at least for a while. For migrants who, at the time of research, were still involved in circular migration, the typical length of a stint working with a reliable employer is seven to ten years. Those who are not able to find stable jobs but who would like to secure employment for longer periods of time, combine two destinations over the course of the 
same year, like Mihai and Ana, who both harvest asparagus in Germany and work in an apple orchard in Italy. Several informants went abroad for longer than six months, usually to Spain. Under contract with one employer, a woman was involved in long-term migration for two out of six years in Spain. Another migrant, who went to Spain for the first time in 2014, currently combines two contracts: she works from March to June in Huelva and, after two weeks' holiday, moves to Valladolid until February.

Reflecting on their trajectories, informants are generally satisfied with their work experiences in the agricultural sector abroad, as it involves considerably higher earnings than the alternatives in their home country. In Lina's words: "What can you do with 18 million a month [ 370 euro], with bills to pay, if you have young children? You go abroad. You go abroad for two months, you return with 5,450 euro, after expenses" (less productive workers earn only 2,000 for the same period). Migrants like her, who have a stable job in Romania, those who combine short-term and long-term migration, as well as those who have moved into other economic sectors, are among the few informants that seem to have improved their socio-economic status in their home country. The vast majority of respondents, however, have used the money earned from seasonal work in agriculture to make ends meet during inactive periods in their home country or for modest household investment. Other studies also show that Romanians involved in seasonal agricultural migration are not consistently able to improve their economic circumstances in their home country (Şerban, Molinero-Gerbeau and Deliu, 2020). Nevertheless, some informants have used earnings to support children in education, therefore contributing to their upward mobility.

\section{Conclusion}

In examining the mobility strategies of Romanian seasonal workers in agriculture from a home country perspective, this paper seeks to contribute to the literature on the agency of temporary migrants (Alberti 2014, Brentsen 2016, Datta et al. 2007, Rogaly 2009). Over the last few decades, every spring 
and summer a consistent number of Romanians have moved abroad, for weeks or even months, to harvest the fields of Germany, Spain and Italy, while their lives, however, have remained centred on their home country. Here, therefore, I aimed to explain how migrants integrate journeys abroad into their lives at the origin and what strategies they use to deal with the insecure terms of employment and the poor conditions in which they often work in host countries.

Drawing on interviews with key informants and seasonal workers in Germany, Spain, Italy, Austria and the U.K., I showed that, rather than being mere victims of external circumstances, migrants actively choose the times and spaces of their mobility, taking into account a variety of factors, including family commitments, economic goals in their home country, wages and working conditions, health issues and welfare opportunities. Informants often decide to remain in such short-term employment, since it allows them to make ends meet while they prioritize their lives in the origin country. Similarly, even though, as a result of their low negotiating capital, they are often not able to challenge precarious working conditions, based on their access to the labour markets of the E.U. Member States, as well as the substantial history of migration to several destinations from their place of origin and its complex migration infrastructure (Xiang and Lindquist 2014), migrants compare wages and working conditions in various locations and move with ease between destinations and jobs (Andrijasevic and Sacchetto 2016).

The findings illustrated that depending on their commitments and objectives, Romanians who work in agriculture develop different mobility practices. While some work abroad only occasionally, when they need to earn more than at the origin, others engage in circular migration or extend the periods of time spent abroad. In host countries, most workers try out various jobs and typically become involved in repeated migration once they have found a suitable arrangement. Some workers combine seasonal work in one or more countries of destination, over the course of the same year, with the aim of securing income for longer periods of time, while others resort to long- 
term migration or move into sectors that offer better opportunities. A comparison with other migrant groups involved in agriculture in host countries showed that, for example, Romanians enjoy a more stable position than African migrants in Italy (Perrota 2013), but are less secure than Polish workers in Germany (Wagner and Hassel 2013, 2016).

Reflecting on their trajectories, informants were generally satisfied with their work experiences and money earned abroad, especially when compared to the alternatives in the country of origin. The earnings, however, were largely used to make ends meet during inactive periods in their home country, as well as for modest household acquisitions and renovation (Şerban, Molinero-Gerbeau and Deliu 2020), and therefore did not contribute to a consistent improvement in their economic circumstances at the origin. However, some migrants have supported children in higher education thereby contributing to their upward mobility.

\section{Acknowledgments}

This research was funded through a Spiru Haret Fellowship at the New Europe College. I am very grateful to the friends who hosted me and agreed to put me in touch with potential informants in their villages and to all my interviews partners, who opened their doors and shared their work and life experiences with me. I would like to thank the two anonymous reviewers for their helpful comments on this paper and to M. Ş. for her advice in the initial stages of this research and for her constant support.

\section{Bibliography}

Alberti, Gabriella. 2014. “Mobility Strategies, 'Mobility Differentials' and 'Transnational Exit': The Experiences of Precarious Migrants in London's Hospitality Jobs." Work, Employment and Society 28 (6): 86581.

Anderson, Bridget. 2007. "Battles in Time: The Relation between Global and Labour Mobilities." Working Paper, University of Oxford 55: 1-23. 
Andrijasevic, Rutvica, and Devi Sacchetti. 2016. "From labour migration to labour mobility? The return of the multinational worker in Europe." Transfer: European Review of Labour and Research 22(2): 219-231.

Bakewell, Oliver. 2010. "Some Reflections on Structure and Agency in Migration Theory." Journal of Ethnic and Migration Studies 36 (10): 16891708.

Berntsen, Lisa. 2015. "Stepping up to strike: a union mobilization case study of Polish migrant workers in the Netherlands", Transfer: European Review of Labour and Research, 21(4): 399-412.

Berntsen, Lisa. 2016. "Reworking Labour Practices." Work, Employment $\mathcal{E}$ Society 30 (3): 472-88.

Corrado, Alessandra, Carlos De Castro and Domenico Perrotta. 2016. Migration and Agriculture: Mobility and Change in the Mediterranean Area. London and New York: Routledge.

Datta, Kavita, Cathy McIlwaine, Yara Evans, Joanna Herbert, Jon May, and Jane Wills. 2007. “From Coping Strategies to Tactics: London's LowPay Economy and Migrant Labour." British Journal of Industrial Relations.

Diminescu, Dana. 2004. “Assessment and Evaluation of Bilateral Labour Agreements Signed by Romania." In Migration for Employment Bilateral Agreements at a Crossroads, 65-74. OECD Publishing.

Gertel, Jürg and Sarah Ruth Sippel. 2014 "Seasonality and temporality in intensive agriculture". In Seasonal Workers in Mediterranean Agriculture: The Social Costs of Eating Fresh. Seasonal Workers in Mediterranean Agriculture: The Social Costs of Eating Fresh, edited by Jürg Gertel and Sarah Ruth Sippel, 3-22. New York: Routledge.

Fiałkowska, Kamila, and Maria Piechowska. 2016. "New Way, Old Pattern. Seasonal Migration from Poland to Germany." Arbor, 192 (777): a287.

Fitzgerald, Ian and Jane Hardy. 2010. "Thinking Outside the Box? Trade Union Organizing Strategies and Polish Migrant Workers in the United Kingdom" British Journal of Industrial Relations, 48(1): 131-150.

Giddens, Anthony. 1984. "Elements of the Theory of Structuration." In The Constitution of Society: Outline of the Theory of Structuration. Cambridge: Polity Press.

Helander, Mika, Peter Holley, and Heidi Uuttana. 2016. “Trying to Secure a Future in Uncertain Circumstances. The Social Security of Temporary Migrant Workers in Finland." Arbor, 192 (777): a287.

Hellio, Emmanuelle. 2008. Importer des femmes pour exporter des fraises (Huelva). Études rurales 182: 185-200.

López-Sala, Ana María. 2016. “Induced Circularity for Selective Workers. The 
Case of Seasonal Labor Mobility Schemes in the Spanish Agriculture." Arbor, 192 (777): a287.

Lawrence, Christopher M. 2007. Blood and Oranges: European Markets and Immigrant Labor in Rural Greece. Berghahn Books.

Mezzadra, Sandro. 2004. “The Right to Escape.” Ephemera, 4(3): 267-275.

Juravich, Tom. 2000. Organizing Immigrants: The Challenges for Unions in Contemporary California. Edited by Ruth Milkman. ILR Press/Cornell University Press.

Molinero-Gerbeau, Yoan, and Gennaro Avallone. 2018. "Migration and Labour Force Needs in Contemporary Agriculture: What Drives States to Implement Temporary Programs? A Comparison among the Cases of Huelva, Lleida (Spain) and Piana Del Sele (Italy)1 2." Calitatea Vieții 29 (1): 3-22.

Nyers, Peter. 2015. "Migrant Citizenships and Autonomous Mobilities." Migration, Mobility, E Displacement 1(1): 23-39.

Papadopoulos, Dimitris, and Vassilis S. Tsianos. 2013. “After Citizenship: Autonomy of Migration, Organisational Ontology and Mobile Commons." Citizenship Studies 17 (2): 178-96.

Perrotta, Domenico. 2013. "Traiettorie migratorie nei territori del pomodoro: rumeni e burkinabé in Puglia e Basilicata." In La globalizzazione delle campagne. Migranti e società rurali nel Sud Italia, edited by Carlo Colloca and Alessandra Corrado, 118-40. Milano: Angeli.

Potot, Swanie. 2003. “Quand les migrants balkaniques rencontrent ceux venus du Sud." Balkanologie Revue d'études pluridisciplinaires 7 (1): 65-85.

Reich, Michael, David M Gordon, and Richard C Edwards. 1973. “Dual Labor Markets: A Theory of Labor Market Segmentation." American Economic Review 63 (2): 359-65.

Rogaly, Ben. 2009. "Spaces of Work and Everyday Life: Labour Geographies and the Agency of Unorganised Temporary Migrant Workers." Geography Compass 3 (6): 1975-87.

Sewell, William H. Jr. 1992. "A Theory of Structure: Duality, Agency, and Transformation." The American Journal of Sociology 98 (1): 1-29.

Smith, Chris. 2006. “The Double Indeterminacy of Labour Power: Labour Effort and Labour Mobility." Work, Employment and Society 20 (2): 389402.

Șerban, Monica, Yoan Molinero Gerbeau and Alexandra Deliu. 2020 "Are the guest-worker programmes still effective? Insights from Romanian migration to Spanish agriculture. In International Migration to Europe's Rural Regions, edited by Johan Frederik Rye and Karen O'Reilly, 22-36. London and New York: Routledge. 
Vlase, Ionela. 2013. “'My Husband Is a Patriot!': Gender and Romanian Family Return Migration from Italy." Journal of Ethnic and Migration Studies 39 (5): 741-58.

Voivozeanu, Alexandra. 2019. "Precarious Posted Migration: The Case of Romanian Construction and Meat-Industry Workers in Germany." Central and Eastern European Migration Review 8 (2): 85-99.

Wagner, Bettina, and Anke Hassel. 2016a. "Posting, Subcontracting and LowWage Employment in the German Meat Industry." Transfer: European Review of Labour and Research 22 (2): 163-78.

Wagner, Bettina, and Anke Hassel. 2016b. "Move to Work, Move to Stay? Mapping Atypical Labour Migration into Germany." In Labour Mobility in the Enlarged Single European Market (Comparative Social Research, Vol. 32), 125-158. Emerald Group Publishing Limited.

Xiang, Biao, and Johan Lindquist. 2014. "Migration Infrastructure." International Migration Review 48 (1): 122-48. 